\title{
Factors Influencing Donation Intention to Personal Medical Crowdfunding Projects Appearing on MSNS
}

\author{
Qihua Liu, Hainan University, China \\ Li Wang, Hainan University, China \\ Jingyi Zhou, Hainan University, China \\ Wei Wu, Huanghuai University, China \& Hainan University, China \\ Yiran Li, Zhejiang University of Technology, China
}

\begin{abstract}
This purpose of this study is to develop a research model by extending the theory of planned behavior in a new application context and apply it to investigate the extrinsic factors influencing people's attitudes towards donating to medical crowdfunding projects appearing on mobile social networking sites (MSNS) and their intention to donate. A survey of 356 Chinese users was conducted and structural equation modeling was used to validate the proposed model and hypotheses. The results indicate that project information, retweeter information, and MSNS information all have a significant effect on the general attitude towards donating to medical crowdfunding projects, and general attitude positively affects people's donation intention. In addition, perceived behavioral control also has a positive effect on people's donation intention, while experienced donating to medical crowdfunding projects has a negative effect on people's donation intention. The research findings provide important theoretical and practical implications.
\end{abstract}

\section{KEYWORDS}

Donation Intention, External Factors, Medical Crowdfunding, Theory of Planned Behavior

\section{INTRODUCTION}

Global health care spending is expected to grow at an annual rate of 5.4\% from 2018 to 2022, a significant increase from the 2.9\% during 2013-2017 (Deloitte, 2019). Personal health care spending is also expected to continue to grow substantially, reaching \$11,674 in the United States in 2022 (Deloitte, 2019). However, not everyone can enjoy good medical support services, such as medical insurance and government subsidies, to help them pay for these expenses. An estimated 97 million people worldwide fell into poverty in 2010 due to out-of-pocket medical expenses (WHO, 2018). In this context, online fundraising for medical expenses, also known as medical crowdfunding, has begun to appear and develop rapidly. Patients and their family members can solicit donations from others on medical crowdfunding platforms to raise unaffordable treatment costs. In the United States, GoFundMe, a popular medical crowdfunding platform, raised about $\$ 1.6$ million from 8,000 projects related to medical expenses, raising $\$ 150$ million from 600,000 projects in 2014 (Snyder, 2016). In China, Shuidichou.cn has successfully provided free fundraising services for more than 800,000 
seriously ill patients with financial difficulties, with a total fundraising amount of more than 16 billion RMB (Shuidichou, 2019). In addition, medical crowdfunding platforms such as Qschou.com and Axzchou.com have also grown rapidly in China. In the future, medical crowdfunding is expected to show a sustained annual growth rate of $25 \%$ (Simon 2016).

With the rapid development of mobile Internet, many medical crowdfunding platforms have begun to turn their attention to mobile social networking sites (MSNS) such as Facebook, WeChat and Weibo. Through MSNS, users can not only connect with others, but also share crowdfunding projects to receive donations from others. As a result, many mobile users are receiving more and more requests to donate to medical crowdfunding projects on MSNS. Unlike charitable donations projects, initiated by charitable organizations or non-profit organizations, medical crowdfunding projects are mostly initiated by family members or friends of patients, which are defined as personal medical crowdfunding projects in this study.

However, many personal medical crowdfunding projects are far short of their targets, leading to a low success rate of crowdfunding (Jin, 2019). For example, analyzing 200 medical crowdfunding projects on the GoFundMe platform, Berlinerhe and Kenworthy (2017) found that only $10 \%$ of the projects achieved their fundraising goals. A statistical study of 143,917 medical crowdfunding projects on the Qschou.com showed that only 7\% of the projects successfully raised the target amount (Guo et al., 2019). Therefore, an important research question is what factors affect users' intention to donate to personal medical crowdfunding projects appearing on MSNS.

Past research on online donation has investigated the factors that influence people's intention to donate online (Treiblmaier and Pollach, 2006; Shier and Handy, 2012; Reddick and Ponomariov, 2012; Mejova et al., 2014). Some studies also have examined the attitude towards donation via social network site (Kim and Lee, 2014; Sura et al., 2017). However, most of these studies focus on online donation behavior towards charitable or non-profit organizations, ignoring individual requests for help. In the context of online crowdfunding, existing research has focus mostly on financial crowdfunding project (Gerber and Hui, 2014; Zheng et al., 2014; Lin and Viswanathan, 2016; Lukkarinen et al., 2016; Zheng et al., 2017). However, there are very limited studies in the available literature on donation intention to personal medical crowdfunding projects. Unlike online donations, medical crowdfunding information spread through MSNS includes not only those provided by MSNS account owners, but also those created by MSNS members. Therefore, we can't determine whether the factors that influence the donation intention to online donation and online crowdfunding also apply to the medical crowdfunding context.

The factors that affect the donation intention to medical crowdfunding include intrinsic and extrinsic factors. Existing literature mainly focuses on intrinsic factors (e.g., empathy, trust, etc.) (Lee and Chang, 2008; Kasri, 2013; Mejova et al., 2014; Ahn et al., 2018), while ignoring the influence of extrinsic factors. However, in the context of medical crowdfunding, donors can easily obtain extrinsic information such as project information, retweeter information and crowdfunding platform information through MSNS. Theory of Planned Behavior (TPB) suggests that extrinsic factors can predict donor behavior well. Moreover, Reeson and Tisdell (2008) and Cherry (2013) both found that extrinsic factors had a crowding out effect on internal factors, i.e., when intrinsic factors caused a low level of donation intention, extrinsic factors could significantly improve the donation intention. In addition, TPB holds that attitude is a direct determinant of behavioral intention. However, in the context of personal medical crowdfunding, the extrinsic factors that affect people's attitudes towards donation have not been fully explored. Therefore, this paper aims to study the under-explored area by specifically investigating the following questions:

RQ1: What extrinsic factors will affect the donation attitude of personal medical crowdfunding projects on MSNS?

RQ2: What extrinsic factors will affect the donation intention of personal medical crowdfunding projects on MSNS? 
To solve these problems, this study develops a research model by extending the theory of planned behavior in a new application context, and applies it to investigate the extrinsic factors that influence people's attitude and intention to donate to medical crowdfunding projects appearing on MSNS. Therefore, an empirical analysis of data obtained from consumer surveys among Chinese users is conducted. The results show that project information, retweeter information and MSNS information all have a significant impact on the general attitude of medical crowdfunding project donation, and the general attitude has a positive impact on people's donation intention. In addition, perceived behavioral control also has a positive effect on people's donation intention, while donation experience has a negative effect on it. However, crowdfunding platform information have no significant impact on people's attitudes towards donations to personal medical crowdfunding projects. Moreover, the influence of subjective norm on donation intention is not significant. This study analyzes the key factors that influence the success of personal medical crowdfunding projects on MSNS from the perspective of users, and provides references for relevant literatures on medical crowdfunding, as well as practical guidance for the founders, retweeters and crowdfunding platforms of personal medical crowdfunding projects.

The rest of the paper is organized as follows. In Section 2, we review the literature related to online donation and online crowdfunding. In Section 3, we construct the research model of this paper and put forward the research hypothesis based on the theory of planned behavior (TPB). Section 4 outlines our data and research methods, while Section 5 presents the reliability, validity, and results of structural equation model (SEM) analysis. Section 6 discusses the research results, and highlights the research significance and future research directions.

\section{LITERATURE REVIEW}

\section{Online Donation}

The rapid development of the Internet has led to the emergence of online donation, which is the alternative way to fundraise because traditional fundraising methods have become inefficient (Hoefer, 2012). To that end, many charities and non-profit organizations have shifted from manual giving to online donation. This provides an opportunity to investigate the motivation and drivers of online donations to charitable or non-profit organizations.

Some studies focus on the influence of intrinsic factors on people's intention of online donations (Mejova et al., 2014; Li, 2017; Liu et al., 2018; Sisco and Weber, 2019; Paramita, 2020). For example, Mejova et al. (2014) found e-mail could capture the demographics of different interest groups, and users were more likely to donate to projects they are interested in. Li (2017) and Liu et al. (2018) suggested that trust and empathy are the key factors which actively affect people's donation intention. Sisco and Weber (2019) used big data to test altruism, kin selection and sex selection motivations of donors to crowdfunding. They found that eleven percent of anonymous donations are attributed to altruistic goals, that donors prefer to give to recipients with the same last name, and that women are more sympathetic than men. Paramita et al. (2020) discovered that pride positively affects the donation decision, but not the amount of the donation, and gratitude has a positive impact on both. However, Reeson and Tisdell (2008) and Cherry (2013) pointed out that when the intrinsic factors are low, leading to a low voluntary donation, the extrinsic factors can significantly increase them, which means the extrinsic factors encourage others to donate. Recently, a growing number of literature studies the influence of extrinsic factors on online donation intention (Treiblmaier and Pollach, 2006; Reddick and Ponomariov, 2012; Sura et al., 2017; Liu et al., 2020; Song and Kim, 2020). Treiblmaier and Pollach (2006) found that the extrinsic factors have significant effects on people's attitude towards online donation, which significantly affects their intention to donate. Reddick and Ponomariov (2012) examined the impact of charitable organizations on people's online donation intention. They found that the higher people's perception of charity organizations, the more likely they were to donate. Song and Kim (2020) found that individuals' attitudes toward non-profit organizations moderated 
the level of time distance to explain their intention to donate. Furthermore, van der Linden (2011) and Knowles et al. (2012) found that attitudes, perceived behavioral control, moral norms, and past behavior can predict donors' intention to donate. However, Sura et al. (2017), Mittelman et al. (2018) and Chen et al. (2019) found different results, which indicated that charity project, charity organization, MSNS features and subjective norm have no significant effect on donation intention. The mixed results suggest that this is still an under-studied problem. Moreover, intrinsic factors have been well tested in prior studies (Lee and Chang, 2008; Kasri, 2013; Mejova et al., 2014; Ahn et al., 2018; Su et al., 2021). Hence, this study focuses on extrinsic factors influencing donation intention to personal medical crowdfunding projects on MSNS.

\section{Online Crowdfunding}

Previous studies have looked at people's motivation for participating in online crowdfunding (Gerber and Hui, 2014; Amara et al., 2014; Cholakova and Clarysse, 2015; Bretschneider and Leimeister, 2017; Zhao et al., 2017; Majumdar and Bose, 2018; Kusumarani and Zo, 2019; Song et al., 2019; RodriguezRicardo et al., 2019). Intrinsic factors such as interest, curiosity, altruism and consistency have been shown to have a significant impact on people's intention to participate in online crowdfunding projects (Bretschneider et al., 2014; Kusumarani and Zo, 2019; Rodriguez-Ricardo et al., 2019). Extrinsic factors such as the presence of rewards, recognition, attitudes and subjective norm have also been found to significantly influence people's participation intention toward reward-based crowdfunding projects (Amara et al., 2014; Shneor and Munim, 2019; Hwang and Lee, 2020). Baber (2020) found that attitudes and subjective norm played a significant role on citizens' intention to participate in political crowdfunding, while perceived behavioral control didn't.

In addition, many studies have focused on the impact of the content and non-content characteristics of crowdfunding proposals (Zheng et al., 2014; Lin et al., 2016; Majumdar and Bose, 2018; Ma et al., 2021; Shiau et al., 2021; Zinko et al., 2021). However, there is little research on altruistic crowdfunding platforms that do not provide clear financial or non-financial benefits to project backers. Katherine and Daniel (2015) proposed the enhanced concept of IT affordability and donor motivation types in the context of charity crowdfunding. Majumdar and Bose (2018) examined the importance of textual factors that determine the success of charity crowdfunding. Conducting an online survey, Dragojlovic and Lynd (2016) found that crowdfunding projects with high potential for cure, such as common diseases and early-onset diseases, had higher success rates in fundraising. Moy et al. (2018) made an empirical analysis of crowdfunding data on Kickstarter platform, and found that there was an inverted U-shaped relationship between text length of crowdfunding projects and fundraising success rate. Durand et al. (2018) suggested that crowdfunding project with more positive emotions, longer description length, higher target amount, and third-person description perspective was positively correlated with more donation amount. Using visualization analysis to study medical crowdfunding projects on the GoFundMe platform, Ren et al. (2020) found that children's help-seeking projects raised more money compared with adults help-seeking projects. Ba et al. (2021) found that healthrelated text features had the most significant impact on the success of medical crowdfunding in China.

A unique but increasingly popular application of crowdfunding is the payment of medical expenses, which has not received much attention in academic literature, namely medical crowdfunding. Moreover, existing research focuses on the economic and social impact (Renwick and Mossialos, 2017; Gonzales et al., 2018; Lukk et al., Burtch and Chan, 2019; An et al., 2021), ethical and privacy issues (Snyder et al., 2017), fraud issues (Zenone and Snyder, 2018), and success factors (Aleksina et al., 2019) of medical crowdfunding. There is still a lack of research on the influencing factors of people's donation intention to medical crowdfunding projects from the perspective of users. The above factors affecting online donation behavior are shown in Table 1. 


\section{RESEARCH MODEL AND HYPOTHESIS}

\section{Research Model}

The theory of planned behavior (TPB) was proposed by Ajzen in 1991. It is an important tool for understanding and predicting human behavior and has been widely used in many studies (Ajzen, 1991; Treiblmaier and Pollach, 2006; Knowles et al., 2012; Zhang et al., 2015; Sura et al., 2017; Shneor and Munim, 2019; Hwang and Lee, 2020). TPB holds that people's behavior is determined by their intentions, which in turn are influenced by attitude, subjective norm, and perceived behavioral control. Specifically, attitude refers to the individual's positive or negative evaluation of behavior (Ajzen, 1991). According to TPB, attitudes towards a particular behavior can significantly influence people's intentions towards that behavior (Ajzen, 1991). The better and stronger the attitude is related to the behavior, the stronger the intention to perform that behavior. However, part of the studies on giving behavior ignores the influence of subjective norm and behavioral control. In medical crowdfunding, they may have an important impact on donation intention. Subjective norm means the perception of whether social pressure will be generated, while behavioral control refers to the perceived ease or difficulty of the behavior, i.e., whether the donors believe they have the ability, knowledge or financial resources to contribute to the crowdfunding campaign of MSNS. Van der Linden (2011) and Knowles et al. (2012) found that attitudes, perceived behavioral control, moral norms, and past behavior can predict donors' intention to donate. Therefore, subjective norm and perceived behavioral control are important factors to explain donation behavior, and their omission means that the application of TPB is imprecise.

In China, a medical crowdfunding project involves project information, crowdfunding platforms information (platform on which medical crowdfunding projects rely, such as Qschou.com, etc.), retweeter information (people who forward crowdfunding requests on MSNS) and MSNS information (such as Facebook, WeChat, Sina weibo, QQ, etc.). Taking a personal medical crowdfunding project appearing on WeChat as an example, as shown in Figure 1, people will see or receive a medical crowdfunding project forwarded by his or her WeChat friends (Retweeters). When looking at the project, people can see the patient information, disease characteristics, fundraising information, and crowdfunding platform information. If people want to donate to the project, they can click the "I'll help too" button to make the payment.

The research model of this study was adapted from Treiblmaier and Pollach (2006) and Sura et al. (2017) by taking TPB into consideration. Considering the specific context of personal medical crowdfunding, we selected four extrinsic factors, which are project information, retweeter information, crowdfunding platform information, and MSNS information, to examine the influence of these factors on people's attitude towards donation. We also studied the impact of attitude, subjective norm and perceived behavioral control on intention to donate. The factor "MSNS information" is adapted from Sura et al. (2017). Treiblmaier and Pollach (2006) and Sura et al. (2017) focused people's donation intention to charitable projects published by charitable organizations, so they considered extrinsic factors including charitable project and charitable organization. Similar to the two research models, this study focused on personal medical crowdfunding, so the extrinsic factors considered included project information, retweeter information, crowdfunding platform information, and MSNS information. In addition, subjective norm and perceived behavioral control have been widely recognized as an important factor affecting online user behavior (Van der Linden, 2011; Knowles et al., 2012; Shneor and Munim, 2019;Hwang and Lee, 2020). Therefore, the research model is shown in Fig. 2.

\section{Hypothesis}

A personal medical crowdfunding project mainly contains three aspects of information: patient information, disease characteristics and fundraising information. Aleksina et al. (2019) pointed out that disease characteristics and fundraising information are important factors influencing the success of medical crowdfunding campaigns. Xu and Wang (2019) indicate that understanding the relevant 
Table 1. Factors influencing online donation behavior

\begin{tabular}{|c|c|c|c|c|}
\hline Literature & $\begin{array}{l}\text { Dependent } \\
\text { Variable }\end{array}$ & $\begin{array}{l}\text { Intrinsic } \\
\text { Factors }\end{array}$ & $\begin{array}{l}\text { Extrinsic } \\
\text { Factors }\end{array}$ & Main findings \\
\hline $\begin{array}{l}\text { Pentecost and Andrews } \\
\text { (2010), van der Linden } \\
\text { (2011), Knowles et al. } \\
\text { (2012) }\end{array}$ & $\begin{array}{l}\text { donation } \\
\text { intention }\end{array}$ & & $\begin{array}{l}\text { attitudes, perceived behavioral } \\
\text { control, moral norms, past } \\
\text { behavior }\end{array}$ & $\begin{array}{l}\text { Attitudes, moral norms, perceived behavioral control, } \\
\text { and past behavior, are all predictors of the intent of } \\
\text { charitable donations. }\end{array}$ \\
\hline $\begin{array}{l}\text { Reddick and } \\
\text { Ponomariov (2012) }\end{array}$ & $\begin{array}{l}\text { donation } \\
\text { intention }\end{array}$ & & charitable organizations & $\begin{array}{l}\text { Higher people's perception of charity organizations, } \\
\text { the more likely they were to donate. }\end{array}$ \\
\hline Amara et al.(2014) & $\begin{array}{l}\text { Participation } \\
\text { intention }\end{array}$ & & recognition & $\begin{array}{l}\text { The recognition of social media and the sense } \\
\text { of belonging of a group positively influence the } \\
\text { participation in a crowdfunding platform. }\end{array}$ \\
\hline $\begin{array}{l}\text { Bretschneider et } \\
\text { al.(2014) }\end{array}$ & $\begin{array}{l}\text { Participation } \\
\text { intention }\end{array}$ & interest, curiosity & & $\begin{array}{l}\text { The sense of curiosity leads to pro-social motivation } \\
\text { for supporters, and interest can produce more } \\
\text { crowdfunding participation. }\end{array}$ \\
\hline Mejova et al. (2014) & $\begin{array}{l}\text { donation } \\
\text { intention }\end{array}$ & interest & & $\begin{array}{l}\text { E-mail could capture the demographics of different } \\
\text { interest groups, and users are more likely to donate to } \\
\text { projects they are interested in. }\end{array}$ \\
\hline $\begin{array}{l}\text { Li (2017), Liu et al. } \\
\text { (2018) }\end{array}$ & $\begin{array}{l}\text { donation } \\
\text { intention }\end{array}$ & empathy, trust & & $\begin{array}{l}\text { Trust and empathy are the key factors that actively } \\
\text { affect people's donation intention. }\end{array}$ \\
\hline Durand et al. (2018) & $\begin{array}{l}\text { donation } \\
\text { amount }\end{array}$ & & $\begin{array}{l}\text { emotions, description } \\
\text { length, target amount, } \\
\text { description perspective }\end{array}$ & $\begin{array}{l}\text { Crowdfunding project, which is more positive } \\
\text { emotions, longer description length, higher target } \\
\text { amount, and third-person description perspective, was } \\
\text { positively correlated with more donation amount. }\end{array}$ \\
\hline $\begin{array}{l}\text { Majumdar and Bose } \\
\text { (2018) }\end{array}$ & $\begin{array}{l}\text { fundraising } \\
\text { success rate }\end{array}$ & & $\begin{array}{l}\text { content features, non- } \\
\text { content features }\end{array}$ & $\begin{array}{l}\text { The presence of money-related descriptions and } \\
\text { references to women in the text increased the } \\
\text { crowdfunding success rate, as did text length and } \\
\text { images. }\end{array}$ \\
\hline Moy et al. (2018) & $\begin{array}{l}\text { fundraising } \\
\text { success rate }\end{array}$ & & text length & $\begin{array}{l}\text { There was an inverted U-shaped relationship between } \\
\text { text length of crowdfunding projects and fundraising } \\
\text { success rate. }\end{array}$ \\
\hline $\begin{array}{l}\text { Rodriguez-Ricardo et } \\
\text { al.(2019) }\end{array}$ & $\begin{array}{l}\text { Participation } \\
\text { intention }\end{array}$ & altruism & & $\begin{array}{l}\text { Altruism and internal locus of control enhance the } \\
\text { trust of crowdfunding, and then affect individuals' } \\
\text { intention to participate. }\end{array}$ \\
\hline $\begin{array}{l}\text { Shneor and } \\
\text { Munim(2019) }\end{array}$ & $\begin{array}{l}\text { Participation } \\
\text { intention }\end{array}$ & & $\begin{array}{l}\text { attitudes, subjective norm, } \\
\text { perceived behavioral control }\end{array}$ & $\begin{array}{l}\text { Attitudes and subjective norm have a positive effect } \\
\text { on crowdfunding participation intention, but perceived } \\
\text { behavioral control has a negative effect. }\end{array}$ \\
\hline Sisco and Weber (2019) & $\begin{array}{l}\text { donation } \\
\text { intention }\end{array}$ & $\begin{array}{l}\text { altruism, kin } \\
\text { selection, } \\
\text { sex selection } \\
\text { motivations }\end{array}$ & & $\begin{array}{l}\text { Eleven percent of anonymous donations are attributed } \\
\text { to altruistic goals, donors prefer to give the same } \\
\text { recipients as their surname, and women are more } \\
\text { sympathetic than men. }\end{array}$ \\
\hline $\begin{array}{l}\text { Baber (2020), Hwang } \\
\text { and Lee }(2020)\end{array}$ & $\begin{array}{l}\text { Participation } \\
\text { intention }\end{array}$ & & attitudes, subjective norm & $\begin{array}{l}\text { Attitudes and subjective norm played a significant } \\
\text { role on citizens' intention to participate in political } \\
\text { crowdfunding. }\end{array}$ \\
\hline Paramita et al. (2020) & $\begin{array}{l}\text { donation } \\
\text { intention }\end{array}$ & pride and gratitude & & $\begin{array}{l}\text { Pride positively affects the donation decision, but not } \\
\text { the amount of the donation. Gratitude has a positive } \\
\text { impact on both. }\end{array}$ \\
\hline Ren et al. (2020) & $\begin{array}{l}\text { donation } \\
\text { amount }\end{array}$ & & age & $\begin{array}{l}\text { Children's help-seeking programs raised more money } \\
\text { compared with adult help-seeking. }\end{array}$ \\
\hline Song and Kim (2020) & $\begin{array}{l}\text { donation } \\
\text { intention }\end{array}$ & & charitable organizations & $\begin{array}{l}\text { Individuals' attitudes toward non-profit organizations } \\
\text { moderated the level of time distance to explain their } \\
\text { intention to donate. }\end{array}$ \\
\hline Ba et al. (2021) & $\begin{array}{l}\text { fundraising } \\
\text { success rate }\end{array}$ & & text features & $\begin{array}{l}\text { Health-related text features had the most significant } \\
\text { impact on the success of medical crowdfunding in } \\
\text { China. }\end{array}$ \\
\hline Liu et al. (2021) & $\begin{array}{l}\text { fundraising } \\
\text { success rate }\end{array}$ & & $\begin{array}{l}\text { disease characteristics, } \\
\text { occupation, age, gender, } \\
\text { emotions }\end{array}$ & $\begin{array}{l}\text { The disease and occupation of the patients had } \\
\text { positive effects on the success rate of fundraising, } \\
\text { while the age, gender and negative emotions had } \\
\text { negative effects. }\end{array}$ \\
\hline
\end{tabular}


Figure 1. A personal medical crowdfunding project appears on WeChat

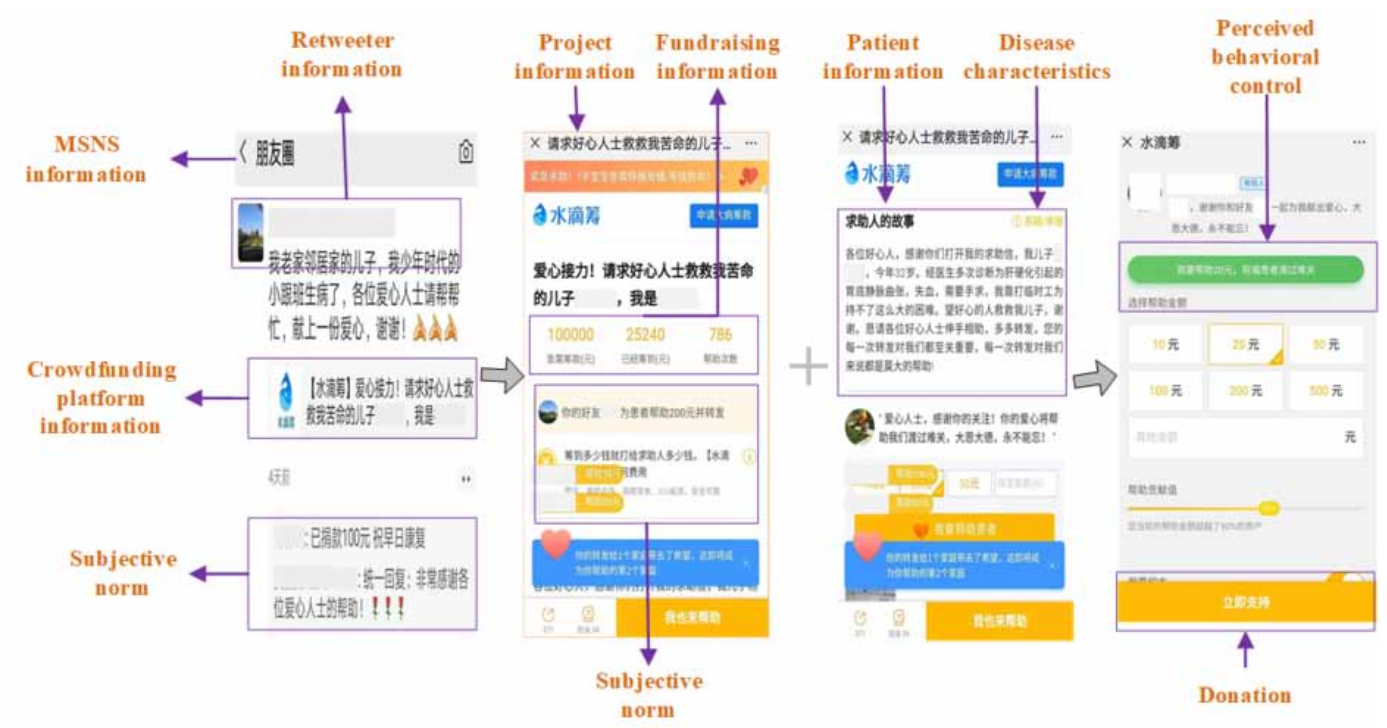

information of patients, especially the value of patients to family and society and their attitude towards life, can help arouse the sense of responsibility and donation motivation of potential donors. Moreover, in the context of online crowdfunding, many studies have found that project information quality (Bi et al., 2017) and project features (Kim et al., 2017) have important effects on people's attitude. Zhang et al. (2021) found that the project information such as the patient's age, occupation, text length and title all affected the fundraising success rate. Thus, we propose that:

H1: A donor's perception on project information has a significant effect on the general attitude towards donating to a personal medical crowdfunding project

Figure 2. Research model

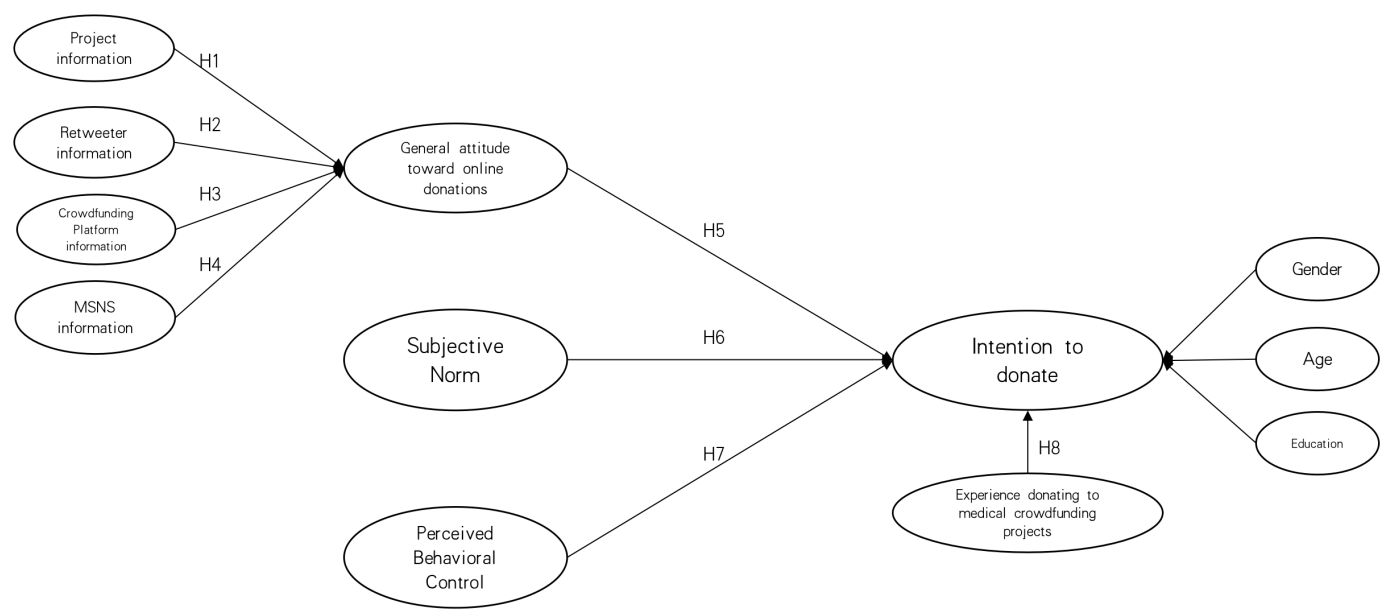


Medical crowdfunding is a way to effectively use MSNS to raise money for health-related expenses. People can send personal medical crowdfunding projects to their friends via MSNS. In this study, these people are referred to as retweeters. Many netizens see medical crowdfunding projects through the actions of these retweeters. Tan et al. (2021) analyzed the charity campaign 'Giving Tuesday' on Twitter and found that the retweeters have positive effect on fundraising performance. Therefore, it can be expected that the perception of the retweeter information may influence people's attitude towards the medical crowdfunding projects, thus affecting the success rate of medical crowdfunding. Accordingly, we propose the following hypothesis:

H2: A donor's perception on retweeter information has a significant effect on the general attitude towards donating to a personal medical crowdfunding project

Crowdfunding platform is an important support for personal medical crowdfunding projects to be initiated and carried on. In China, most crowdfunding platforms, such as Qschou.com and Axzchou.com, are often responsible for verifying the authenticity of information related to medical crowdfunding projects and managing the received money from donation. When many people decide whether to make a charitable donation, they often worry about whether the money they donate will be used properly or cheated. In fact, with the rapid development of medical crowdfunding, fraud may also appear and increase rapidly. Medical crowdfunding fraud can be observed in a number of ways, such as pretending to be sick, not using money for the intended purpose of a campaign, or pretending to be a legitimate patient (Snyder, 2016; Zenone and Snyder, 2018). Zhang et al. (2021) found that the web page design of medical crowdfunding platforms affects the trust of donors. Therefore, belief and perception of a crowdfunding platform information may play a key role on people's attitude towards donation of medical crowdfunding projects relying on that platform. Strohmaier et al. (2019) have found that an individual's perception of institutional mechanisms of crowdfunding platforms affects their views and attitudes towards crowdfunding projects on these platforms. Accordingly, we propose the following hypothesis:

H3: A donor's perception on crowdfunding platform information has a significant effect on the general attitude towards donating to a personal medical crowdfunding project

MSNS are information-sharing places that offer a variety of functions that stimulate emotions, attitudes, and beliefs(Cheikh-Ammar and Barki, 2016). As a result, MSNS are the foundation for the wide spread and success of many personal medical crowdfunding projects. Many people get access to personal medical crowdfunding projects through MSNS. Moreover, prior studies have found that MSNS information may significantly affect people's attitude towards online donation (Castillo et al., 2014; Kim and Lee, 2014). Xiao (2021) found that there was asymmetry in the security perception of mobile users from a micro perspective. Therefore, we can expect that MSNS information will have important effect on people's attitude towards personal medical crowdfunding projects. Accordingly, we propose the following hypothesis:

H4: A donor's perception on MSNS information has a significant effect on the general attitude towards donating to a personal medical crowdfunding project

The attitude towards a particular behavior has a direct and significant impact on the intention to perform the behavior (Ajzen, 1991). Prior studies have found that people's attitude towards online donation has a significant effect on their donation intention (Treiblmaier and Pollach, 2006; Knowles et al. 2012; Kim and Lee, 2014). Adapted from Ajzen (1991) and Sura et al. (2017), this study defined attitude as the degree to which a person feels and perceives donations to medical crowdfunding projects, 
that is, a person's favorable impression, aversion or evaluation of donations to medical crowdfunding projects. Accordingly, we propose the following hypothesis:

H5: A donor's attitude towards donating to a personal medical crowdfunding project positively influences the intention to donate

When a person clicks on a link to a personal medical crowdfunding project on MSNS, he or she can see all of their friends' donations. The crowdfunding platform will pop up some messages to remind him or her that those friends have donated. Moreover, a friend who has donated to the project can also use this information to find out if he or she has also donated. In this study, we refer to the effect of donations from friends as subjective norm. Webb et al. (2000), Teng et al. (2015), Ha and Janda (2017) all found that subjective norm is an important determinant of individuals' behavioral intention. In the context of charitable donation, Van der Linden (2011) and Knowles et al. (2012) all suggested that subjective norm contributes to an individual's intention to donate. Thus, we propose that:

H6: A donor's perception on subjective norm has a significant effect on intention towards donating to a personal medical crowdfunding project

Perceived behavioral control is the perceived ease or difficulty of performing an action, reflecting past experience and expected obstacles (Ajzen, 1991). Individuals are more likely to donate when they feel that the act of giving is achievable. Among the three elements of TPB model, perceived behavioral control is considered to be one of the important factors. Numerous literatures have found that perceived behavioral control has a significant positive effect on individuals' behavioral intentions (Albayrak et al., 2013; Chen and Tung, 2014; Teng et al., 2015; Saha and Chandra, 2018). In the field of medical crowdfunding, Smith and McSweeney (2007) and Chen et al. (2019) have found that perceived behavioral control has a positive impact on individuals' intention to donate. Therefore, we propose the following hypothesis:

H7: A donor's perception on perceived behavioral control has a significant effect on intention towards donating to a personal medical crowdfunding project

Research has shown that an individual's past experience may influence their intention to donate and their behavior. On mobile social networking sites, supporters fall into three categories, including those who have never donated before, those who have relatively little donation experience (once or twice), and those who have more donation experience (three to five times) (Hughes, 1984). Godin et al. (2007) found significant differences between experienced donors and new donors in terms of the determinants of their intention to donate. As the level of past experience increases, past experience becomes a better predictor of behavior (Hughes, 1984). Some literature that studied giving behavior has found that supporters with giving experience show more positive giving behavior than those without experience (Bednall et al., 2013; Hyung-Shik and Young-Shim, 2014). Therefore, we propose the following hypothesis:

H8: A donor's donation experience has a significant positive effect on intention towards donating to a personal medical crowdfunding project 


\section{RESEARCH METHOD}

\section{Data Collection}

A survey was conducted in China from January 1, 2021 to February 1, 2021 to empirically validate the research model. The questionnaire was released through Wenjuanxing, which is the largest professional survey service platform in China. The survey invitations with the URL of the questionnaire were spread through e-mail, QQ, Wechat, Sina Microblog and DingTalk to allow more users to participate. As a motivation for participation, we paid for every valid respondent 5 RMB.

IBM SPSS Statistics 26.0 was used to analyse the samples and provide descriptive results. Furthermore, partial least squares structural equation modeling (PLS-SEM) was used to analyse our research model. Compared with covariance-based structural equation modeling (CB-SEM), which has minimal demands in terms of measurement scale, sample size and residual distributions (Chin et al., 2003), PLS-SEM relaxes normal distributional assumptions (Hair et al., 2019; Khan et al., 2019; Shiau et al., 2019; Shiau and Chau, 2016). Moreover, this study adopts a prediction perspective for the analysis, and PLS-SEM maximizes the variance of endogenous variables explained by exogenous variables (Hair et al., 2016). The predictive focus is appropriate for meeting the objectives of the study. The above reasons support our decision that PLS is an appropriate method for this study. According to the recommendation of Anderson and Gerbing (1988), a two-stage process was employed for the data analysis: the measurement model and structural model assessment. The measurement model assessment examines reliability and validity, while the structural model assessment allows hypothesis testing by examining the relationships among constructs.

\section{Descriptive Statistics}

In total, 356 responses were received. In this survey, we set up a question to determine whether a respondent had experience with MSNS. If not, the survey is immediately completed and the questionnaire he or she filled out is eliminated. This survey also used a function of missing data detection to ensure the completeness of the questionnaire. However, many responses were completed much faster than expected. Such a quick response usually indicates that some participants filled out the questionnaire irresponsibly. Forty subjects completed the pretest before the formal questionnaire was distributed. The pretest results showed that it took at least 200 seconds to complete the questionnaire at a normal pace. As a result, we removed responses from the formal questionnaire that took less than 200 seconds. In addition, we also scrutinized and eliminated those questionnaires, which had the same answers to all questions. Finally, 284 valid responses were obtained. As shown in Table 2, $41.9 \%$ of the respondents were male and $58.1 \%$ were female, with $44.4 \%$ of them were between 29 and 35 years old. $75.4 \%$ of the respondents had or were receiving college education. $25.7 \%$ of the respondents have the amount of money available each month of 3,000 to 5,000 Yuan. The gender and age distribution in our sample is similar to the official data released by the China Internet Information Center (CNNIC) at the end of 2018(CNNIC, 2018). However, the level of education in our sample was is slightly higher than reported, possibly due to the characteristics of our sample location (for example, proximity to a university). The distribution of the money available each month is basically consistent with the report on resident income and consumer spending released by China's National Bureau of Statistics in 2019 (NBS, 2019).

\section{Nonresponse Bias}

Non-response bias refers to the fact that people do not respond to a questionnaire, which may lead to bias in research results. Armstrong and Overton (1977) found that compared with early respondents, later respondents are more likely to be non-respondents. Consistent with the procedure proposed by Armstrong and Overton (1977), we address this problem by comparing the gender and age of early and later respondents.

Therefore, we divided the questionnaire respondents according to the response time period. In general, our questionnaire distribution cycle lasts for one month. We regard the respondents in 
the first half of the month as early respondents, and those in the second half as later respondents. The recovered 284 valid questionnaires showed that 150 subjects were early respondents and 134 were later respondents. The results of the chi-square test showed that there was no significant difference in gender and age between the early and later respondents $(P>0.05)$. Therefore, we rule out the possibility of non-response bias.

\section{Common Method Bias}

When there is a single source of research data, common method bias will appear, which will seriously threaten the authority of research results. Our questionnaire is distributed online through Wenjuanxing platform, so the distribution group is not limited to a certain region or group. It means that there is no single data source problem. However, when a factor accounts for more than $50 \%$ of the covariance, common method bias is likely to exist (Mattila and Enz, 2002). Therefore, we still tested whether there was common method bias in the research data. First, we performed Harman's one-factor test on the constructs (Podsakoff and Organ, 1986). The results of principal component factor analysis showed that the total interpretation level of the covariance of the eight constructs in this paper was $72.78 \%$, among which the highest interpretation level of a single construct was $31.82 \%$ (the interpretation range of covariance of a single factor ranged from $3.35 \%$ to $31.82 \%$ ). That is to say, there is no single variable that can explain all indicators. Second, consistent with previous studies, we also used marker variable method for testing (Chin et al., 2012). The results showed that the marker variables had no significant effect on the project information, retweeter information, crowdfunding platform information, MSNS information, general attitude toward online donations, subjective norm, perceived behavioral control, and intention to donate. Therefore, the research data in this paper did not have the threat of common method bias.

\section{Measurement Development}

Our questionnaire consists of two parts. The first part is demographic characteristics factors including gender, age, education, etc. The second part includes 8 constructs, such as project information, retweeter information, crowdfunding platform information, MSNS information, general attitude toward online donations, subjective norm, perceived behavioral control, and intention to donate. All items are adapted from authoritative literature to apply to the medical crowdfunding context. With the exception of demographic characteristics information, all items used the five-point Likert scale anchored at $1=$ "strongly disagree" to 5 = "strongly agree".

As shown in Appendix A., project information was measured with 5 items adapted from Sura et al. (2017). Retweeter information was assessed with 5 items adapted from Wang et al. (2019). Crowdfunding platform information was measured using a five-item scale adapted from Sura et al. (2017). MSNS information was operationalized with 4 items adapted from Sura et al. (2017). General attitude toward online donations was composed of 3 items which are developed by Ajzen (1991) and Nemme and White (2010). Subjective norm was measure with 4 items from Xu et al. (2014). Perceived behavioral control also contains four items. These items were adapted from Ajzen (1991). Intention to donate was consist of 3 items adapted from Sura et al. (2017).

In order to ensure the quality of the questionnaire and the smooth progress of the survey in China, the questionnaire for this study was first designed in English and then translated into Chinese. Considering the reliability of the Chinese translation, all the original texts were translated into Chinese by two authors with overseas study experience. Next, a professional translator whose native language was Chinese confirmed the meaning of the English version by comparing the two Chinese versions. If there is any disagreement, the researchers will discuss the translation method until a consensus is reached. 
Table 2. Descriptive statistics of respondents' characteristics

\begin{tabular}{|c|c|c|c|}
\hline Variables & Category & Frequency & Percentage \\
\hline \multirow[t]{2}{*}{ Gender } & Male & 119 & $41.9 \%$ \\
\hline & Female & 165 & $58.1 \%$ \\
\hline \multirow{5}{*}{ Age } & $\begin{array}{l}>17 \\
18-28\end{array}$ & $\begin{array}{l}1 \\
94\end{array}$ & $\begin{array}{l}0.4 \% \\
33.1 \%\end{array}$ \\
\hline & $29-35$ & 126 & $44.4 \%$ \\
\hline & $36-44$ & 45 & $15.8 \%$ \\
\hline & $45-59$ & 16 & $5.6 \%$ \\
\hline & $>60$ & 2 & $0.7 \%$ \\
\hline \multirow{5}{*}{ Education } & High School and below & 11 & $3.9 \%$ \\
\hline & College education & 32 & $11.3 \%$ \\
\hline & Bachelor & 214 & $75.4 \%$ \\
\hline & Master & 25 & $8.8 \%$ \\
\hline & Doctor & 2 & $0.7 \%$ \\
\hline \multirow{5}{*}{$\begin{array}{l}\text { The amount of money available } \\
\text { each month }\end{array}$} & $<1000$ & 10 & $3.5 \%$ \\
\hline & $1000-3000$ & 63 & $22.2 \%$ \\
\hline & $3000-5000$ & 73 & $25.7 \%$ \\
\hline & $5000-8000$ & 72 & $25.4 \%$ \\
\hline & $>8000$ & 66 & $23.2 \%$ \\
\hline $\begin{array}{l}\text { Experience donating to medical } \\
\text { crowdfunding projects }\end{array}$ & $\begin{array}{l}\text { Once or more } \\
\text { Not once }\end{array}$ & $\begin{array}{l}241 \\
43\end{array}$ & $\begin{array}{l}84.9 .0 \% \\
15.1 \%\end{array}$ \\
\hline
\end{tabular}

\section{DATA ANALYSIS AND RESULTS}

The collected data was analyzed using SPSS 26.0 and SmartPLS 3.0. The measurement model testing was used to test the reliability and validity of the measurement scale of each construction. The structural model testing was used to test the hypothesis.

\section{Measurement Model}

Confirmatory factor analysis (CFA) was used in this paper to ensure the reliability and validity of constructs. Consistent with previous studies, Cronbach's alpha and composite reliability (CR) were calculated to measure the reliability of constructs (Joreskog's, 1971; Babozzi and Phillips, 1982). As shown in Table 3, all Cronbach's alpha coefficients were between 0.801 and 0.897 , and CR scores were ranged from 0.865 to 0.936 , which were higher than the recommended value 0.6 (Balozzi and Phillips, 1982). The test of constructs validity in this research includes convergent validity and discriminate validity. On the one hand, the convergent validity was confirmed by factor loading and the values of average variance extraction (AVE) (Babozzi and Phillips, 1982; Wixom and Watson, 2007). Table 3 shows that the factor loading of all items ranged from 0.716 to 0.929 , exceeding the threshold level of 0.5 (Wixom and Watson, 2007). And the minimum AVE value for each construct is 0.593 (ranging from 0.593 to 0.829 ), which is above the recommended level of 0.5 (Fornell and Larcker, 1981). On the other hand, we evaluated discriminate validity by examining Fornell-Larcker criterion and heterotraitmonotrait ratio (HTMT). As shown in Table 4, the square root of AVE was greater than the correlation of each construct. While Franke and Sarstedt (2019) suggested that the threshold value for HTMT 
should be based on the research context, Henseler et al. (2014) advised that it could be relaxed to 0.9 at most. Table 5 shows that the maximum HTMT value of this research was 0.672 (ranged from 0.234 to 0.672 ), less than the threshold level of 0.9 . Therefore, constructs in this paper have great reliability and validity.

\section{Structural Model}

Partial least squares method (PLS) was used in this paper to evaluate the structural model, which was mainly realized by evaluating the interpretation level of the overall model (i.e., the value of $R^{2}$ ) and path coefficient (Hou et al., 2011; Hsieh et al., 2012; Xu et al., 2014). Consistent with previous studies, after determining a satisfactory measurement model, 1000 random samples were generated by bootstrapping procedure in this paper, which were used to evaluate the significance of the path coefficient and indicator loadings of the measurement model (Wixom and Todd, 2005; Lin et al., 2014).

As shown in Figure 3, project information $(\beta=0.257, p<0.001)$, retweeter information $(\beta=0.246$, $p<0.001)$, MSNS information $(\beta=0.308, p<0.001)$ significantly and positively affected general attitude toward online donations. And general attitude toward online donations $(\beta=0.213, p<0.001)$, perceived behavioral control $(\beta=0.440, p<0.001)$, have the significant and positive effect on the intention to donate. Therefore, H1, H2, H4, H5, H7 are supported. However, crowdfunding platform information ( $\beta=-0.040, p>0.1)$ cannot exert a significant influence on the general attitude toward online donations. And we found no significant effect of subjective norm $(\beta=0.009, p>0.1)$ on the intention to donate. Thus, $\mathrm{H} 3$ and $\mathrm{H} 6$ are rejected. In addition, in the control variables, gender $(\beta=-0.070, p>0.1)$, age $(\beta=-0.061, p>0.1)$ and education degree $(\beta=0.035, p>0.1)$ had no significant effect on the intention to donate. However, experience donating to medical crowdfunding projects $(\beta=-0.178, P<0.01)$ significantly and negatively affected the intention to donate. Therefore, $\mathrm{H} 8$ is rejected.

Table 3. Convergent validity analysis results

\begin{tabular}{|c|c|c|c|c|c|c|c|c|}
\hline Constructs & Items & $\begin{array}{l}\text { Item } \\
\text { mean }\end{array}$ & $\begin{array}{l}\text { Standard } \\
\text { deviation }\end{array}$ & $\begin{array}{l}\text { Standardized } \\
\text { item loading }\end{array}$ & $\begin{array}{l}\text { T- } \\
\text { statistic }\end{array}$ & $\begin{array}{l}\text { Cronbach's } \\
\text { alpha }\end{array}$ & $\mathbf{C R}$ & AVE \\
\hline Project information (PI) & $\begin{array}{l}\text { PI } 1 \\
\text { PI } 2 \\
\text { PI } 3 \\
\text { PI } 4 \\
\text { PI } 5\end{array}$ & $\begin{array}{l}3.98 \\
4.42 \\
4.21 \\
3.95 \\
3.69\end{array}$ & $\begin{array}{l}0.790 \\
0.822 \\
0.806 \\
0.900 \\
1.138\end{array}$ & $\begin{array}{l}0.734 \\
0.771 \\
0.794 \\
0.716 \\
0.829\end{array}$ & $\begin{array}{l}21.867 \\
32.384 \\
30.843 \\
20.710 \\
39.900\end{array}$ & 0.827 & 0.879 & 0.593 \\
\hline Retweeter information (RI) & $\begin{array}{l}\text { RI } 1 \\
\text { RI } 2 \\
\text { RI } 3\end{array}$ & $\begin{array}{l}3.31 \\
4.13 \\
3.84\end{array}$ & $\begin{array}{l}1.204 \\
0.882 \\
0.989\end{array}$ & $\begin{array}{l}0.901 \\
0.816 \\
0.891\end{array}$ & $\begin{array}{l}72.871 \\
27.229 \\
65.221\end{array}$ & 0.841 & 0.903 & 0.757 \\
\hline $\begin{array}{l}\text { Crowdfunding platform } \\
\text { information (CI) }\end{array}$ & $\begin{array}{l}\text { FI1 } \\
\text { FI2 } \\
\text { FI3 }\end{array}$ & $\begin{array}{l}4.40 \\
4.45 \\
4.38\end{array}$ & $\begin{array}{l}0.673 \\
0.743 \\
0.763\end{array}$ & $\begin{array}{l}0.824 \\
0.923 \\
0.814\end{array}$ & $\begin{array}{l}15.317 \\
36.386 \\
18.198\end{array}$ & 0.819 & 0.890 & 0.731 \\
\hline MSNS information (MI) & $\begin{array}{l}\text { PIF } 1 \\
\text { PIF } 2 \\
\text { PIF } 3\end{array}$ & $\begin{array}{l}3.66 \\
3.66 \\
3.32\end{array}$ & $\begin{array}{l}1.073 \\
1.079 \\
1.165\end{array}$ & $\begin{array}{l}0.924 \\
0.885 \\
0.902\end{array}$ & $\begin{array}{l}91.614 \\
57.784 \\
78.035\end{array}$ & 0.888 & 0.931 & 0.817 \\
\hline $\begin{array}{l}\text { General attitude toward } \\
\text { online donations (GD) }\end{array}$ & $\begin{array}{l}\text { PIC1 } \\
\text { PIC2 } \\
\text { PIC3 }\end{array}$ & $\begin{array}{l}3.69 \\
3.52 \\
3.62\end{array}$ & $\begin{array}{l}1.135 \\
1.055 \\
1.024\end{array}$ & $\begin{array}{l}0.885 \\
0.916 \\
0.929\end{array}$ & $\begin{array}{l}62.246 \\
65.143 \\
78.662\end{array}$ & 0.897 & 0.936 & 0.829 \\
\hline Subjective Norm (SN) & $\begin{array}{l}\text { IOD1 } \\
\text { IOD2 } \\
\text { IOD3 } \\
\text { IOD4 }\end{array}$ & $\begin{array}{l}4.05 \\
3.83 \\
4.00 \\
4.01\end{array}$ & $\begin{array}{l}0.929 \\
1.045 \\
0.902 \\
0.882\end{array}$ & $\begin{array}{l}0.752 \\
0.788 \\
0.829 \\
0.770\end{array}$ & $\begin{array}{l}18.625 \\
18.648 \\
23.636 \\
18.783\end{array}$ & 0.801 & 0.865 & 0.617 \\
\hline $\begin{array}{l}\text { Perceived behavioral control } \\
\text { (PC) }\end{array}$ & $\begin{array}{l}\mathrm{PC} 1 \\
\mathrm{PC} 2 \\
\mathrm{PC} 3\end{array}$ & $\begin{array}{l}4.05 \\
4.31 \\
3.99\end{array}$ & $\begin{array}{l}0.828 \\
0.755 \\
0.841\end{array}$ & $\begin{array}{l}0.869 \\
0.864 \\
0.849\end{array}$ & $\begin{array}{l}45.769 \\
45.231 \\
43.257\end{array}$ & 0.825 & 0.895 & 0.740 \\
\hline Intention to donate (ID) & $\begin{array}{l}\text { ID1 } \\
\text { ID2 } \\
\text { ID3 }\end{array}$ & $\begin{array}{l}4.00 \\
4.01 \\
4.13\end{array}$ & $\begin{array}{l}0.786 \\
0.836 \\
0.828\end{array}$ & $\begin{array}{l}0.830 \\
0.850 \\
0.886\end{array}$ & $\begin{array}{l}30.117 \\
38.871 \\
69.058\end{array}$ & 0.818 & 0.891 & 0.732 \\
\hline
\end{tabular}


Table 4. Discriminant validity: Fornell-Larcker criterion

\begin{tabular}{|l|l|l|l|l|l|l|l|l|}
\hline & $\mathbf{1}$ & $\mathbf{2}$ & $\mathbf{3}$ & $\mathbf{4}$ & $\mathbf{5}$ & $\mathbf{6}$ & $\mathbf{7}$ & $\mathbf{8}$ \\
\hline 1. SN & $\mathbf{0 . 7 8 5}$ & & & & & & & \\
\hline 2. PC & 0.438 & $\mathbf{0 . 8 6 0}$ & & & & & & \\
\hline 3. GD & 0.402 & 0.388 & $\mathbf{0 . 9 1 1}$ & & & & & \\
\hline 4. ID & 0.291 & 0.559 & 0.403 & $\mathbf{0 . 8 5 6}$ & & & & \\
\hline 5. CI & 0.241 & 0.373 & 0.211 & 0.287 & $\mathbf{0 . 8 5 5}$ & & & \\
\hline 6. PI & 0.393 & 0.378 & 0.440 & 0.414 & 0.319 & $\mathbf{0 . 7 7 0}$ & & \\
\hline 7. MI & 0.303 & 0.352 & 0.420 & 0.210 & 0.261 & 0.236 & $\mathbf{0 . 9 0 4}$ & \\
\hline 8. RI & 0.420 & 0.452 & 0.436 & 0.378 & 0.361 & 0.497 & 0.248 & $\mathbf{0 . 8 7 0}$ \\
\hline
\end{tabular}

Table 5. Discriminant validity: Heterotrsait-monotrait (HTMT)

\begin{tabular}{|l|l|l|l|l|l|l|l|}
\hline & $\mathbf{1}$ & $\mathbf{2}$ & $\mathbf{3}$ & $\mathbf{4}$ & $\mathbf{5}$ & $\mathbf{6}$ & $\mathbf{7}$ \\
\hline 1. SN & & & & & & & \\
\hline 2. PC & 0.537 & & & & & & \\
\hline 3. GD & 0.465 & 0.450 & & & & & \\
\hline 4. ID & 0.328 & 0.672 & 0.463 & & & & \\
\hline 5. CI & 0.283 & 0.457 & 0.234 & 0.349 & & & \\
\hline 6. PI & 0.476 & 0.456 & 0.508 & 0.495 & 0.395 & & \\
\hline 7. MI & 0.371 & 0.411 & 0.469 & 0.241 & 0.312 & 0.275 & \\
\hline 8. RI & 0.495 & 0.534 & 0.491 & 0.449 & 0.437 & 0.593 & 0.279 \\
\hline
\end{tabular}

Figure 3. Results of the structural model

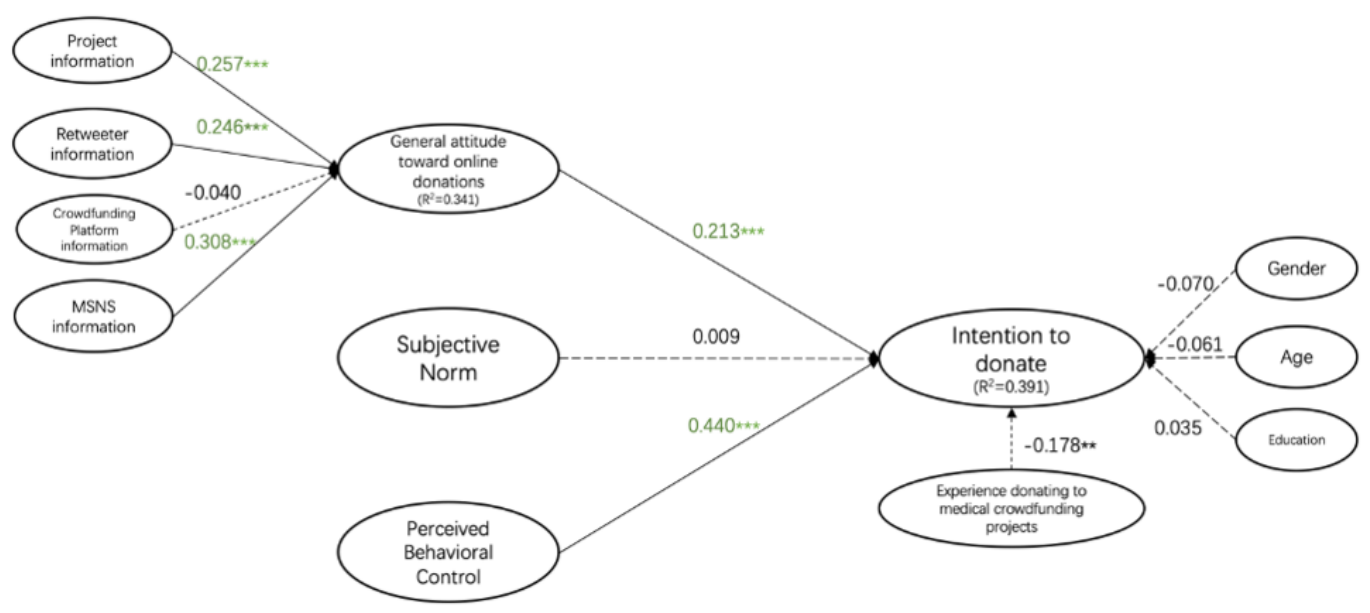

Note: $* * *: \mathrm{p}<0.001, * *: \mathrm{p}<0.01, *: \mathrm{p}<0.05$, Dash Line: $\mathrm{p}>0.05$ 


\section{DISCUSSION}

The purpose of this study is to propose a research model based on TPB to investigate what extrinsic factors affect people's attitude towards donating to a personal medical crowdfunding project appearing on MSNS and their intention to donate. A survey of 356 Chinese users was conducted and structural equation modeling was used to validate the proposed model and hypotheses. Overall, five hypotheses were supported and three were rejected.

The results showed that a donor's perception on project information positively affects his or her attitude towards donating to a personal medical crowdfunding project. This result is consistent with previous studies, which suggested that project information have important effects on people's attitude toward online crowdfunding (Bi et al., 2017; Kim et al., 2017). This result is also similar to prior research in medical crowdfunding, which pointed out that disease characteristics, fundraising information, and relevant information of patient are important factors influencing the success of a medical crowdfunding project (Aleksina et al., 2019; Xu and Wang, 2019).

Second, the results also confirmed that a donor's perception on retweeter information positively influence his or her attitude towards donating to a personal medical crowdfunding project. Many people see a request for personal medical crowdfunding only after a link forwarded by the retweeter. This result means that choosing who to forward personal medical crowdfunding requests is also important, which is similar to the findings of Liang et al. (2019).

Third, the results also suggested that MSNS information has significant effects on people's attitude towards donating to a personal medical crowdfunding project. The results for MSNS information are in line with the findings of Ahn et al. (2018), which indicated that MSNS information has significant effect on people's overall attitude towards online donation on Malaysian.

Fourth, the results also confirmed that people's attitude towards donating to a personal medical crowdfunding project positively affects his or her intention to donate. This result is consistent with previous studies on online donation (Treiblmaier and Pollach, 2006; Kim and Lee, 2014; Sura et al. 2017). Moreover, this finding is in line with the prediction of TPB, which points out that attitude is the direct determinant of behavioral intention.

Additionally, the results also showed the positive effect of perceived behavioral control on the intention to donate to personal medical crowdfunding projects. This is consistent with previous research on online giving (Smith and McSweeney, 2007; Chen et al., 2019). It means that the ease of giving is critical to the success of online donating.

For controlled variables, the results indicated that people without experience donating to personal medical crowdfunding projects are more likely to generate donation intention towards a personal medical crowdfunding project. The finding is not in accordance with the result of Liang et al. (2019). The reasons for this may be as follows. Fistly, experienced donors worry about the uncertain direction of their donations and are not sure whether they can help patients. Secondly, experienced donors have doubts about the platform handling fee. Finally, experienced donors are more likely to question the authenticity of medical crowdfunding projects.

\section{CONCLUSION}

Based on the MSNS context, this study combined with TPB to build a research model to investigate the extrinsic factors that affect people's attitude towards donating to medical crowdfunding projects and their intention to donate. The model explains 34 percent of general donating attitudes and 39 percent of donating intentions. The results show that general attitude of medical crowdfunding project donation is mainly predicted by project information, retweeter information and MSNS information, and the influence of crowdfunding platform information is not significant. Moreover, the general attitude of medical crowdfunding project donation and perceived behavioral control have a positive impact on donation intention, while subjective norm have no significant effect. Therefore, 
crowdfunding platforms and fundraisers should focus on project information, retweeter information and MSNS information in addition to recognizing the importance of general attitude of donating to medical crowdfunding project and perceived behavioral control. Doing so can increase users' donation intention, which in turn can improve the success rate of personal medical crowdfunding.

\section{Implication for Theory and Practice}

This research offers important theoretical implications in the following ways. Firstly, this research contributes to the online crowdfunding literature. Although more and more attention has been paid to online crowdfunding, existing research on medical crowdfunding is far from enough. To our best knowledge, this research is the first to investigate the factors influencing donation intention to personal medical crowdfunding project appearing on MSNS. Moreover, previous studies have analyzed the determinants of crowdfunding success based on the data already generated (Zheng et al., 2014; Lin et al., 2016; Majumdar and Bose, 2018). However, this study can be considered as an early attempt to analyze the key factors influencing the success of crowdfunding projects from the perspective of users.

Secondly, adapted from Treiblmaier and Pollach (2006) and Sura et al. (2017), this study added project information, retweeter information, crowdfunding platform information and MSNS information on the basis of TPB model, developing a research model in a new application context. Moreover, this research applied the extending model to study the factors affecting people's intention to donate to medical crowdfunding, contributing to the literature on online donation.

Thirdly, considering the research context of personal medical crowdfunding and MSNS, the effects of retweeter, subjective norm and perceived behavioral control were examined, which were rarely considered in previous studies. The research findings provided by this study contribute to the medical crowdfunding literature by discovering the significant effects of retweeter and perceived behavioral control.

Finally, this research conducted a survey of Chinese consumers and compared the results with other studies. Therefore, this study is also helpful for future studies to compare the factors influencing the behavioral intentions of potential donors of personal medical crowdfunding in different countries from a cross-cultural perspective. In fact, consumers with different cultural orientations have different donation intentions and behaviors (Gauher et al., 2013; Dean et al., 2018; Ahn et al., 2018).

This study also provided several practical implications for personal medical crowdfunding participants, including founders, retweeters and crowdfunding platforms. First, the founder of a medical crowdfunding project needs to describe in detail the characteristics related to the disease, the patient and his/her family, as well as the proposed goals and the deadline of crowdfunding, etc. At the same time, crowdfunding platforms need to make rules that require creators to provide the above information and timely announce the fundraising status of each project.

Second, founders should choose to launch personal medical crowdfunding projects on platforms that people consider reputable. Meanwhile, the crowdfunding platform should formulate effective rules to prevent the occurrence of fraud, and timely disclose the whereabouts of the funds raised by each project so as to form a good image in people's mind.

Third, founders of personal medical crowdfunding projects and crowdfunding platforms need to pay attention to the significant effect of retweeter on the attitudes of potential donors. They can try to use various methods to find people with good reputation and strong appeal among their friends as retweeters.

Finally, the results indicate that, in China, personal medical crowdfunding participants do not have to worry about the issues caused by the technology characteristics of mobile Internet and MSNS, such as security and privacy.

\section{Limitations and Future Work}

Of course, this study also has some limitations. First, the study only surveyed Chinese users, so the findings may not necessarily apply to other countries. Future research can compare the factors that 
influence potential donors' intention to donate to personal medical crowdfunding projects in different countries from a cross-cultural perspective. Second, because the intrinsic factors influencing online donation intentions have been well tested in previous studies, this study focused on the extrinsic factors influencing people's donation intentions toward personal medical crowdfunding projects and ignored the intrinsic factors. However, considering the medical crowdfunding situation, both intrinsic and extrinsic factors play a major role in influencing people's intention to donate. This remains a question that needs to be studied in the future. Moreover, in the context of personal medical crowdfunding, the effectiveness of previous studies on intrinsic factors affecting online donation intention needs to be re-examined. Finally, this study investigated donation intention rather than actual donation behavior. The present findings would be strengthened if they could be replicated in studies that measure actual donation behavior.

\section{ACKNOWLEDGMENT}

This study is supported by the National Natural Science Foundation of China (Grant numbers 71764006 and 71861013), Hainan Provincial Natural Science Foundation of China (No. 720RC572), Research Foundation of Zhejiang University of Technology (Grant number 2021132001529), and Science Research Foundation of Hainan University (Grant number kyqd(sk)1932). The corresponding author would like to thank Professor Wen-Lung Shiau, the Intelligent Data Analysis Center (IDAC of Zhejiang University of Technology), for his support.

Dr. Yiran Li is the corresponding author of this paper. 


\section{REFERENCES}

Ahn, J. C., Sura, S., \& An, J. C. (2018). Intention to donate via social network sites (SNSs): A comparison study between Malaysian and South Korean users. Information Technology \& People, 31(4), 910-926. doi:10.1108/ ITP-12-2015-0307

Ajzen, I. (1991). The theory of planned behavior. Organizational Behavior and Human Decision Processes, 50(2), 179-211. doi:10.1016/0749-5978(91)90020-T

Albayrak, T., Aksoy, S., \& Caber, M. (2013). The effect of environmental concern and scepticism on green purchase behaviour. Marketing Intelligence \& Planning, 31(1), 27-39. doi:10.1108/02634501311292902

Aleksina, A., Akulenka, S., \& Lublóy, A. (2019). Success factors of crowdfunding campaigns in medical research: Perceptions and reality. Drug Discovery Today, 24(7), 1413-1420. doi:10.1016/j.drudis.2019.05.012 PMID:31132416

AmaraM.CheikhA. B.AbdellatifT. (2014). Crowdfunding: Determinants and motivations of the contributors to the crowdfunding platforms. SSRN. 10.2139/ssrn.2552168

An, L., Hu, J., Xu, M., Li, G., \& Yu, C. (2021). Profiling the users of high influence on social media in the context of public events. Journal of Database Management, 32(2), 36-49. doi:10.4018/JDM.2021040103

Anderson, J. C., \& Gerbing, D. W. (1988). Structural equation modeling in practice: A review and recommended two-step approach. Psychological Bulletin, 103(3), 411-423. doi:10.1037/0033-2909.103.3.411

Armstrong, J. S., \& Overton, T. S. (1977). Estimating nonresponse bias in mail surveys. JMR, Journal of Marketing Research, 14(3), 396-402. doi:10.1177/002224377701400320

Ba, Z., Zhao, Y., Song, S., \& Zhu, Q. (2021). Understanding the determinants of online medical crowdfunding project success in China. Information Processing \& Management, 58(2), 102465. doi:10.1016/j.ipm.2020.102465

Baber, H. (2020). Intentions to participate in political crowdfunding- from the perspective of civic voluntarism model and theory of planned behavior. Technology in Society, 63, 101435. doi:10.1016/j.techsoc.2020.101435

Bagozzi, R. P., \& Phillips, L. W. (1982). Representing and testing organizational theories: A holistic construal. Administrative Science Quarterly, 27(3), 459-489. doi:10.2307/2392322

Bednall, T. C., Bove, L. L., Cheetham, A., \& Murray, A. L. (2013). A systematic review and meta-analysis of antecedents of blood donation behavior and intentions. Social Science \& Medicine, 96, 86-94. doi:10.1016/j. socscimed.2013.07.022 PMID:24034955

Berliner, L. S., \& Kenworthy, N. J. (2017). Producing a worthy illness: Personal crowdfunding amidst financial crisis. Social Science \& Medicine, 187, 233-242. doi:10.1016/j.socscimed.2017.02.008 PMID:28274601

Bi, S., Liu, Z., \& Usman, K. (2017). The influence of online information on investing decisions of reward-based crowdfunding. Journal of Business Research, 71, 10-18. doi:10.1016/j.jbusres.2016.10.001

Bradburn, N. M. (1992). Presidential address: A response to the non-response problem. Public Opinion Quarterly, 56(3), 391-398. doi:10.1093/poq/56.3.391

Bretschneider, U., \& Leimeister, J. M. (2017). Not just an ego-trip: Exploring backers' motivation for funding in incentive-based crowdfunding. The Journal of Strategic Information Systems, 26(4), 246-260. doi:10.1016/j. jsis.2017.02.002

Burtch, G., \& Chan, J. (2019). Investigating the relationship between medical crowdfunding and personal bankruptcy in the United States: Evidence of a digital divide. Management Information Systems Quarterly, 43(1), 237-262. doi:10.25300/MISQ/2019/14569

Castillo, M., Petrie, R., \& Wardell, C. (2014). Fundraising through online social networks: A field experiment on peer-to-peer solicitation. Journal of Public Economics, 114, 29-35. doi:10.1016/j.jpubeco.2014.01.002

Chan, D. C. N., Wu, A. M. S., \& Hung, E. P. W. (2010). Invulnerability and the intention to drink and drive: An application of the theory of planned behavior. Accident; Analysis and Prevention, 42(6), 1549-1555. doi:10.1016/j. aap.2010.03.011 PMID:20728602 
Cheikh-Ammar, M., \& Barki, H. (2016). The implications of social influence theory on continuance intention for social networking among chinese university students. Journal of Organizational and End User Computing, 28(4), 55-72. doi:10.4018/JOEUC.2016100104

Chen, M. F., \& Tung, P. J. (2014). Developing an extended theory of planned behavior model to predict consumers' intention to visit green hotels. International Journal of Hospitality Management, 36, 221-230. doi:10.1016/j. ijhm.2013.09.006

Chen, Y. G., Dai, R. Y., Yao, J. R., \& Li, Y. X. (2019). Donate time or money? The determinants of donation intention in online crowdfunding. Sustainability, 11(16), 4269. doi:10.3390/su11164269

Cherry, K. (2013). What is the difference between extrinsic and intrinsic motivation? Available at: http:// psychology.about.com/od/motivation/f/difference-between-extrinsic-and-intrinsic-motivation.htm

Chin, W. W., Marcolin, B. L., \& Newsted, P. R. (2003). A partial least squares latent variable modeling approach for measuring interaction effects: Results from a monte carlo simulation study and an electronic-mail emotion/ adoption study. Information Systems Research, 14(2), 189-217. doi:10.1287/isre.14.2.189.16018

Chin, W. W., Thatcher, J. B., \& Wright, R. T. (2012). Assessing common method bias: Problems with the ULMC technique. Management Information Systems Quarterly, 36(3), 1003-1019. doi:10.2307/41703491

Cholakova, M., \& Clarysse, B. (2015). Does the possibility to make equity investments in crowdfunding projects crowd out reward-based investments? Entrepreneurship Theory and Practice, 39(1), 145-172. doi:10.1111/ etap.12139

CNNIC. (2018). The 42nd Statistical Report on Internet Development in China. Available at: http://www.cnnic. cn/hlwfzyj/hlwxzbg/hlwtjbg/201808/t20180820_70488.htm

Costello, A., \& Osborne, J. (2005). Best practice in exploratory factor analysis: Four recommendations for getting the most from your analysis. Practical Assessment, Research \& Evaluation, 10(7), 1-9.

Couper, M. P. (2000). Web surveys: A review of issues and approaches. Public Opinion Quarterly, 64(4), 464-494. doi:10.1086/318641 PMID:11171027

Dean, B. W., Hewitt, S. N., Begos, M. C., Gomez, A., \& Messam, L. L. M. V. (2018). An analysis of blood donation barriers experienced by North American and Caribbean university students in Grenada, West Indies. Transfusion and Apheresis Science, 57(1), 40-45. doi:10.1016/j.transci.2017.11.026 PMID:29249628

Deloitte. (2019). Global health care outlook. Available at: https://www2.deloitte.com/global/en/pages/lifesciences-and-healthcare/articles/global-health-care-sector-outlook.html

Dragojlovic, N., \& Lynd, L. D. (2016). What will the crowd fund? Preferences of prospective donors for drug development fundraising campaigns. Drug Discovery Today, 21(12), 1863-1868. doi:10.1016/j. drudis.2016.07.002 PMID:27422268

Durand, W. M., Peters, J. L., Eltorai, A. E. M., Kalagara, S., Osband, A. J., \& Daniels, A. H. (2018). Medical crowdfunding for organ transplantation. Clinical Transplantation, 32(6), e13267. doi:10.1111/ctr.13267 PMID:29683220

Fornell, C., \& Larcker, D. (1981). Evaluating structural equation models with unobservable variables and measurement error. JMR, Journal of Marketing Research, 18(1), 39-50. doi:10.1177/002224378101800104

Fornell, C., \& Larcker, D. F. (1981). Evaluating structural equation models with unobservable variables and measurement error. JMR, Journal of Marketing Research, 18(1), 39-50. doi:10.1177/002224378101800104

Franke, G., \& Sarstedt, M. (2019). Heuristics versus statistics in discriminant validity testing: A comparison of four procedures. Internet Research, 29(3), 430-447. doi:10.1108/IntR-12-2017-0515

Gauher, S. T., Khehar, R., Rajput, G., Hayat, A., Bakshi, B., Chawla, H., Cox, B. M., \& Warrens, A. N. (2013). The factors that influence attitudes toward organ donation for transplantation among UK university students of Indian and Pakistani descent. Clinical Transplantation, 27(3), 359-367. doi:10.1111/ctr.12096 PMID:23406516

Gerber, E. M., \& Hui, J. (2014). Crowdfunding motivations and deterrents for participation. ACM Transactions on Computer-Human Interaction, 20(6), 34-32. 
Godin, G., Conner, M., Sheeran, P., Belanger-Gravel, A., \& Germain, M. (2007). Determinants of repeated blood donation among new and experienced blood donors. Transfusion, 47(9), 1607-1615. doi:10.1111/j.15372995.2007.01331.x PMID:17725724

Gonzales, A. L., Kwon, W. Y., Lynch, T., \& Fritz, N. (2018). Better everyone should know our business than we lose our house: Costs and benefits of medical crowdfunding for support, privacy, and identity. New Media \& Society, 20(2), 641-658. doi:10.1177/1461444816667723

Guo, X. Y., Jiang, J. X., \& Yang, Y. F. (2019). 150 thousand data interpretation of serious disease crowdfunding: Who can raise the saving money? The Paper News.

Ha, H. Y., \& Janda, S. (2017). Predicting consumer intentions to purchase energy-efficient products. Journal of Consumer Marketing, 29(7), 461-469. doi:10.1108/07363761211274974

Hair, J. F., Ringle, C. M., \& Sarstedt, M. (2011). PLS-SEM: Indeed a silver bullet. Journal of Marketing Theory and Practice, 19(2), 139-152. doi:10.2753/MTP1069-6679190202

Hair, J. F., Hult, G. T. M., Ringle, C. M., \& Sarstedt, M. (2016). A Primer on Partial Least Squares Structural Equation Modeling (PLS-SEM). Sage.

Hair, J. F., Risher, J. J., Sarstedt, M., \& Ringle, C. M. (2019). When to use and how to report the results of PLSSEM. European Business Review, 31(1), 2-24. doi:10.1108/EBR-11-2018-0203

Henseler, J., Ringle, C. M., \& Sarstedt, M. (2014). A new criterion for assessing discriminant validity in variance-based structural equation modeling. Journal of the Academy of Marketing Science, 43(1), 115-135. doi:10.1007/s11747-014-0403-8

Hoefer, R. (2012). From website visitor to online contributor: Three Internet fundraising techniques for nonprofits. Social Work, 57(4), 361-365. doi:10.1093/sw/sws002 PMID:23285836

Hughes, R. A. (1984). The interrelationship of attitude and past experience in the prediction of volunteer and donating behavior [Unpublished Doctoral Dissertation]. Catholic University, Washington, DC.

Hwang, N., \& Lee, S. Y. (2020). A study on participation intention and herd behavior on domestic securities type crowdfunding investors: Focusing on the theory of planned behavior. Asia-Pacific Journal of Business Venturing and Entrepreneurship, 15(2), 1-18.

Hyung-Shik, J., \& Young-Shim, K. (2014). A study of the relationships between giving behavior and quality of life on charity donors: Focusing on the moderating role of past donation experience. Korean Npo Review, 13(1), 115-141.

Jin, P. (2019). Medical crowdfunding in China: Empirics and ethics. Journal of Medical Ethics, 45(8), 538-544. doi:10.1136/medethics-2018-105054 PMID:31217228

Joreskog, K. G. (1971). Simultaneous factor analysis in several populations. Psychometrika, 36(4), 409-426. doi:10.1007/BF02291366

Kasri, R. A. (2013). Giving behavior in Indonesia: Motives and marketing implications for Islamic charities. Journal of Islamic Marketing, 4(3), 306-324. doi:10.1108/JIMA-05-2011-0044

Khan, G. F., Sarstedt, M., Shiau, W. L., Hair, J. F., Ringle, C. M., \& Fritze, M. P. (2019). Methodological research on partial least squares structural equation modeling (PLS-SEM): An analysis based on social network approaches. Internet Research, 29(3), 407-429. doi:10.1108/IntR-12-2017-0509

Kim, T., Por, M. H., \& Yang, S. B. (2017). Winning the crowd in online fundraising platforms: The roles of founder and project features. Electronic Commerce Research and Applications, 25, 86-94. doi:10.1016/j. elerap.2017.09.002

Kim, Y., \& Lee, W. (2014). Networking for philanthropy: Increasing volunteer behavior via social networking sites. Cyberpsychology, Behavior, and Social Networking, 17(3), 160-165. doi:10.1089/cyber.2012.0415 PMID:24102569

Knowles, S. S., Hyde, M. K., \& White, K. M. (2012). Predictors of young people's charitable intentions to donate money: An extended theory of planned behavior perspective. Journal of Applied Social Psychology, 42(9), 2096-2110. doi:10.1111/j.1559-1816.2012.00932.x 
Kusumarani, R., \& Zo, H. (2019). Why people participate in online political crowdfunding: A civic voluntarism perspective. Telematics and Informatics, 41, 168-181. doi:10.1016/j.tele.2019.04.011

Lee, Y. K., \& Chang, C. T. (2008). Intrinsic or extrinsic? Determinants affecting donation behaviors. International Journal of Educational Advancement, 8(1), 13-24. doi:10.1057/ijea.2008.2

$\mathrm{Li}$, Q. (2017). Research on impact factors for online donation behavior of bank customer. The Journal of Finance and Data Science, 3(1-4), 13-19. doi:10.1016/j.jfds.2017.09.001

Liang, T. P., Wu, S. P. J., \& Huang, C. (2019). Why funders invest in crowdfunding projects: Role of trust from the dual-process perspective. Information \& Management, 56(1), 70-84. doi:10.1016/j.im.2018.07.002

Lin, M., \& Viswanathan, S. (2016). Home bias in online investments: An empirical study of an online crowdfunding market. Management Science, 62(5), 1393-1414. doi:10.1287/mnsc.2015.2206

Liu, F. Z., Xue, S., Wu, J., Zhou, C., Hu, W. B., Paris, C., Nepal, S., Yang, J., \& Yu, P. S. (2020). Deep learning for community detection: Progress, challenges and opportunities. IJCAI (United States), •••, 4981-4987. doi:10.24963/ijcai.2020/693

Liu, L., Suh, A., \& Wagner, C. (2018). Empathy or perceived credibility? An empirical study on individual donation behavior in charitable crowdfunding. Internet Research, 28(3), 623-651. doi:10.1108/IntR-06-2017-0240

Liu, Q. H., Zhang, B. Q., Wang, L., Zhang, X. Y., \& Li, Y. R. (2021). Information cascades and online shopping: A cross-cultural comparative study in China and the United States. Journal of Global Information Management, 29(3), 26-45. doi:10.4018/JGIM.2021050102

Lukkarinen, A., Teich, J. E., Wallenius, H., \& Wallenius, J. (2016). Success drivers of online equity crowdfunding campaigns. Decision Support Systems, 87, 26-38. doi:10.1016/j.dss.2016.04.006

Ma, X. X., Wu, J., Xue, S., Yang, J., Sheng, Q. Z., \& Xiong, H. (2021). A Comprehensive Survey on Graph Anomaly Detection with Deep Learning. arXiv, preprint arXiv:2106.07178.

Majumdar, A., \& Bose, I. (2018). My words for your pizza: An analysis of persuasive narratives in online crowdfunding. Information \& Management, 55(6), 781-794. doi:10.1016/j.im.2018.03.007

Mattila, A. S., \& Enz, C. A. (2002). The role of emotions in service encounters. Journal of Service Research, 4(4), 267-277. doi:10.1177/1094670502004004004

Mejova, Y., Garimella, V. R. K., Weber, I., \& Dougal, M. (2014). Giving is caring: understanding donation behavior through email. Proceedings of the 17th ACM conference on Computer supported cooperative work \& social computing, 1297-1307. doi:10.1145/2531602.2531611

Mittelman, R., \& Rojas-Méndez, J. (2018). Why Canadians give to charity: An extended theory of planned behaviour model. International Review on Public and Nonprofit Marketing, 15(2), 189-204. doi:10.1007/ s12208-018-0197-3

Moy, N., Chan, H. F., \& Torgler, B. (2018). How much is too much? The effects of information quantity on crowdfunding performance. PLoS One, 13(3), e0192012. doi:10.1371/journal.pone.0192012 PMID:29538371

NBS. (2019). Household income and consumer spending in 2019. Available at: http://www.stats.gov.cn/tjsj/ zxfb/202001/t20200117_1723396.html

Nemme, H. E., \& White, K. M. (2010). Texting while driving: Psychosocial influences on young people's texting intentions and behaviour. Accident; Analysis and Prevention, 42(4), 1257-1265. doi:10.1016/j.aap.2010.01.019 PMID:20441840

Paramita, W., Septianto, F., \& Tjiptono, F. (2020). The distinct effects of gratitude and pride on donation choice and amount. Journal of Retailing and Consumer Services, 53, 101972. doi:10.1016/j.jretconser.2019.101972

Pentecost, R., \& Andrews, L. (2010). Differences between students and non-student's willingness to donate to a charitable organization. International Journal of Nonprofit and Voluntary Sector Marketing, 15(2), 122-136. doi: $10.1002 /$ nvsm.362

Podsakoff, P. M., \& Organ, D. W. (1986). Self-reports in organizational research: Problems and prospects. Journal of Management, 12(4), 531-544. doi:10.1177/014920638601200408 
Reddick, C. G., \& Ponomariov, B. (2012). The effect of Individuals' organization affiliation on their internet donations. Nonprofit and Voluntary Sector Quarterly, 42(6), 1197-1223. doi:10.1177/0899764012452670

Reeson, A., \& Tisdell, J. G. (2008). Institutions, motivations and public goods: An experimental test of motivational crowding. Journal of Economic Behavior \& Organization, 68(1), 273-281. doi:10.1016/j.jebo.2008.04.002

Ren, J., Raghupathi, V., \& Raghupathi, W. (2020). Understanding the dimensions of medical crowdfunding: A visual analytics approach. Journal of Medical Internet Research, 22(7), e18813. doi:10.2196/18813 PMID:32618573

Renwick, M. J., \& Mossialos, E. (2017). Crowdfunding our health: Economic risks and benefits. Social Science \& Medicine, 191, 48-56. doi:10.1016/j.socscimed.2017.08.035 PMID:28889030

Rodriguez-Ricardo, Y., Sicilia, M., \& López, M. (2019). Altruism and internal locus of control as determinants of the intention to participate in crowdfunding: The mediating role of trust. Journal of Theoretical and Applied Electronic Commerce Research, 14(3), 1-16. doi:10.4067/S0718-18762019000300102

Saha, S., \& Chandra, B. (2018). Understanding the underlying motives and intention among Indian blood donors towards voluntary blood donation: A cross-sectional study. Transfusion Clinique et Biologique, 25(2), $109-117$. doi:10.1016/j.tracli.2018.01.002 PMID:29472138

Shiau, W. L., \& Chau, P. Y. K. (2016). Understanding behavioral intention to use a cloud computing classroom: A multiple model comparison approach. Information \& Management, 53(3), 355-365. doi:10.1016/j.im.2015.10.004

Shiau, W. L., Sarstedt, M., \& Hair, J. F. (2019). Internet research using partial least squares structural equation modeling (PLS-SEM). Internet Research, 29(3), 398-406. doi:10.1108/IntR-10-2018-0447

Shiau, W. L., Siau, K., Yu, Y., \& Guo, J. (2021). Research commentary on IS/IT role in emergency and pandemic management: Current and future research. Journal of Database Management, 32(2), 67-75. doi:10.4018/ JDM.2021040105

Shier, M. L., \& Handy, F. (2012). Understanding online behavior: The role of donor characteristics, perceptions of internet, website and program and influence from social networks. International Journal of Nonprofit and Voluntary Sector Marketing, 17(3), 219-230. doi:10.1002/nvsm.1425

Shneor, R., \& Munim, Z. H. (2019). Reward crowdfunding contribution as planned behaviour: An extended framework. Journal of Business Research, 103, 56-70. doi:10.1016/j.jbusres.2019.06.013

Shuidichou. (2019). About shuidichou. Available at: https://www.shuidichou.cn/

Simon, R. (2016), Crowdfunding sites like GoFundMe and YouCaring raise money and concerns. Available at: https://www.wsj.com/articles/crowdfunding-sites-likegofundme-and-youcaring-raise-moneyandconcerns-1456775949

Sisco, M. R., \& Weber, E. U. (2019). Examining charitable giving in real-world online donations. Nature Communications, 10(1), 3968. doi:10.1038/s41467-019-11852-z PMID:31481650

Smith, J. R., \& McSweeney, A. (2007). Charitable giving: The effectiveness of a revised theory of planned behaviour model in predicting donating intentions and behaviour. Journal of Community \& Applied Social Psychology, 17(5), 363-386. doi:10.1002/casp.906

Snyder, J. (2016). Crowdfunding for medical care: Ethical issues in an emerging health care funding practice. The Hastings Center Report, 46(6), 36-42. doi:10.1002/hast.645 PMID:27875643

Snyder, J., Crooks, V. A., Mathers, A., \& White, P. C. (2017). Appealing to the crowd: Ethical justifications in Canadian medical crowdfunding campaigns. Journal of Medical Ethics, 43(6), 364-367. doi:10.1136/ medethics-2016-103933 PMID:28137998

Song, D., \& Kim, D. H. (2020). 'I'll donate money today and time tomorrow': The moderating role of attitude toward nonprofit organizations on donation intention. International Journal of Nonprofit and Voluntary Sector Marketing, 25(3), e1659. doi:10.1002/nvsm.1659

Song, Y., Wu, H., Ma, J., \& Lu, N. (2019). Exploring the dynamic influences and interaction effects of signals on backers' investment in the crowdfunding market. Information Technology \& People, 33(2), $792-812$. doi:10.1108/ITP-04-2019-0174 
Strohmaier, D., Zeng, J., \& Hafeez, M. (2019). Trust, distrust, and crowdfunding: A study on perceptions of institutional mechanisms. Telematics and Informatics, 43, 101252. doi:10.1016/j.tele.2019.101252

Su, X., Xue, S., Liu, F. Z., Wu, J., Yang, J., Zhou, C., Hu, W. B., Paris, C., Nepal, S., \& Jin, D. (2021). A Comprehensive Survey on Community Detection with Deep Learning. arXiv, preprint arXiv:2105.12584.

Sura, S., Ahn, J., \& Lee, O. (2017). Factors influencing intention to donate via social network site (SNS): From Asian's perspective. Telematics and Informatics, 34(1), 164-176. doi:10.1016/j.tele.2016.04.007

Tan, X., Lu, Y. D., \& Tan, Y. (2021). The Impact of Subscription Reciprocity on Charitable Content Creation and Sharing: Evidence from Twitter on Giving Tuesday. Management Information Systems Quarterly, 45(2), 535-562. doi:10.25300/MISQ/2021/14676

Teng, Y. M., Wu, K. S., \& Liu, H. H. (2015). Integrating altruism and the theory of planned behavior to predict patronage intention of a green hotel. Journal of Hospitality \& Tourism Research (Washington, D.C.), 39(3), 299-315. doi:10.1177/1096348012471383

Treiblmaier, H., \& Pollach, I. (2006). A framework for measuring people's intention to donate online. Pacific Asia Conference on Information Systems, 808-817.

Van der Linden, S. (2011). Charitable intent: A moral or social construct? A revised theory of planned behavior model. Current Psychology (New Brunswick, N.J.), 30(4), 355-374. doi:10.1007/s12144-011-9122-1

Voorhees, C. M., Brady, M. K., Calantone, R., \& Ramirez, E. (2016). Discriminant validity testing in marketing: An analysis, causes for concern, and proposed remedies. Journal of the Academy of Marketing Science, 44(1), 119-134. doi:10.1007/s11747-015-0455-4

Wang, X., Lin, X., \& Spencer, M. K. (2019). Exploring the effects of extrinsic motivation on consumer behaviors in social commerce: Revealing consumers' perceptions of social commerce benefits. International Journal of Information Management, 45, 163-175. doi:10.1016/j.ijinfomgt.2018.11.010

Webb, D. J., Green, C. L., \& Brashear, T. G. (2000). Development and validation of scales to measure attitudes influencing monetary donations to charitable organizations. Journal of the Academy of Marketing Science, 28(2), 299-309. doi:10.1177/0092070300282010

WHO. (2018). World health statistics 2018: monitoring health for the SDGs, sustainable development goals. Available at: https://www.who.int/gho/publications/world_health_statistics/2018/en/

Wixom, B. H., \& Watson, H. J. (2007). An empirical investigation of the factors affecting data warehousing success. Management Information Systems Quarterly, 25(1), 17-41. doi:10.2307/3250957

Xiao, Q. (2021). Understanding the asymmetric perceptions of smartphone security from security feature perspective: A comparative study. Telematics and Informatics, 58, 101535. doi:10.1016/j.tele.2020.101535

Xu, K., \& Wang, X. (2019). "Kindhearted people, please save my family": Narrative strategies for new media medical crowdfunding. Health Communication, 35(13), 1605-1613. doi:10.1080/10410236.2019.1654173 PMID:31455114

Xu, Y., Yang, Y., Cheng, Z., \& Lim, J. (2014). Retaining and attracting users in social networking services: An empirical investigation of cyber migration. The Journal of Strategic Information Systems, 23(3), 239-253. doi:10.1016/j.jsis.2014.03.002

Zenone, M., \& Snyder, J. (2018). Fraud in medical crowdfunding: A typology of publicized cases and policy recommendations. Policy and Internet, 11(2), 215-234. doi:10.1002/poi3.188

Zhang, F. G., Xue, B. Y., Li, Y. R., Li, H., \& Liu, Q. H. (2021). The effect of textual features on the success of medical crowdfunding: Evidence from tencent charity platform. Journal of Medical Internet Research, 23(6), e22395. doi:10.2196/22395 PMID:34114959

Zhang, W., Yang, X., Wang, Q. S., Zheng, C. D., \& Sia, C. L. (2015). Investigation on the factors determining consumers' use of online intermediated shopping (ois): A behavioral intention perspective. Journal of Organizational and End User Computing, 27(1), 77-97. doi:10.4018/joeuc.2015010104 
Zhang, X., Hu, W., \& Xiao, Q. (2021). Influences of medical crowdfunding website design features on trust and intention to donate: Controlled laboratory experiment. Journal of Medical Internet Research, 23(5), e25554. doi:10.2196/25554 PMID:33944787

Zhao, Q., Chen, C. D., Wang, J. L., \& Chen, P. C. (2017). Determinants of backers' funding intention in crowdfunding: Social exchange theory and regulatory focus. Telematics and Informatics, 34(1), 370-384. doi:10.1016/j.tele.2016.06.006

Zheng, H. C., Xu, B., Wang, T., \& Xu, Y. (2017). An empirical study of sponsor satisfaction in reward-based crowdfunding. Journal of Electronic Commerce Research, 18(3), 269-285.

Zheng, H., Li, D., Wu, J., \& Xu, Y. (2014). The role of multidimensional social capital in crowdfunding: A comparative study in China and US. Information \& Management, 51(4), 488-496. doi:10.1016/j.im.2014.03.003

Zinko, R., de Burgh-Woodman, H., Furner, Z. Z., \& Kim, S. J. (2021). Seeing is believing: The effects of images on trust and purchase intent in eWOM for hedonic and utilitarian products. Journal of Organizational and End User Computing, 33(2), 85-104. doi:10.4018/JOEUC.20210301.oa5 


\section{APPENDIX A - CONSTRUCTS AND ITEMS}

\section{Table 6. Constructs and Items}

\begin{tabular}{|c|c|c|}
\hline Constructs & Items & Sources \\
\hline \multirow[t]{5}{*}{ Project information } & 1. I choose to donate because of the disease type. & \multirow{5}{*}{$\begin{array}{l}\text { Partially adapted from } \\
\text { Sura et al. (2017) }\end{array}$} \\
\hline & 2. I choose to donate because of the severity of the disease. & \\
\hline & 3. I choose to donate because of the diagnostic evidence of the disease. & \\
\hline & 4. I choose to donate because of the difficulty of curing the disease. & \\
\hline & $\begin{array}{l}5 \text {. I choose to donate because of the degree to which diseases are concerned } \\
\text { by society. }\end{array}$ & \\
\hline Retweeter information & $\begin{array}{l}\text { 1.I prefer to donate to the personal medical crowdfunding project } \\
\text { forwarded by retweeters with high visibility. } \\
\text { 2.I prefer to donate to the personal medical crowdfunding project } \\
\text { forwarded by retweeters with good reputation. } \\
\text { 3.If the retweeter has the same interest or similar experience as me, I prefer } \\
\text { to donate the personal medical crowdfunding project he or she retweets. }\end{array}$ & $\begin{array}{l}\text { Partially adapted from } \\
\text { Wang et al. (2019) }\end{array}$ \\
\hline $\begin{array}{l}\text { Crowdfunding platform } \\
\text { information }\end{array}$ & $\begin{array}{l}\text { 1. I donate only to personal medical crowdfunding projects through } \\
\text { familiar crowdfunding platforms. } \\
\text { 2. I donate only to personal medical crowdfunding projects through } \\
\text { crowdfunding platforms that transparent in managing money donation. } \\
\text { 3. I donate only to personal medical crowdfunding projects through } \\
\text { crowdfunding platforms that I have attached to it. }\end{array}$ & $\begin{array}{l}\text { Adapted from Sura et al. } \\
(2017)\end{array}$ \\
\hline MSNS information & $\begin{array}{l}\text { 1. I donate only to personal medical crowdfunding projects that appear on } \\
\text { familiar MSNS. } \\
\text { 2. I only donate to personal medical crowdfunding projects that appear on } \\
\text { MSNS where the communication features are fully utilized. } \\
\text { 3. I only donate to personal medical crowdfunding projects that appear on } \\
\text { MSNS with interactive features. }\end{array}$ & $\begin{array}{l}\text { Adapted from Sura et al. } \\
(2017)\end{array}$ \\
\hline $\begin{array}{l}\text { General attitude toward } \\
\text { online donations }\end{array}$ & $\begin{array}{l}\text { 1. I think it's good to make personal donations to patients on mobile social } \\
\text { platforms. } \\
\text { 2. I think there is value in making personal donations to patients on mobile } \\
\text { social platforms. } \\
\text { 3. I think there is positive in making personal donations to patients on } \\
\text { mobile social platforms. }\end{array}$ & $\begin{array}{l}\text { Ajzen (1991); Nemme } \\
\text { and White (2010) }\end{array}$ \\
\hline Subjective Norm & $\begin{array}{l}\text { 1. I prefer to donate to medical crowdfunding projects that someone } \\
\text { important to me have also donated. } \\
\text { 2. It is important to me that whether important people have donated to } \\
\text { other personal medical crowdfunding projects. } \\
\text { 3. It's important for me that whether important people support me donate } \\
\text { or not. } \\
\text { 4. Important people' views on donations to personal medical crowdfunding } \\
\text { projects are important to me. }\end{array}$ & $\begin{array}{l}\text { Partially adapted from } \mathrm{Xu} \\
\text { et al. (2014) }\end{array}$ \\
\hline Perceived Behavioral Control & $\begin{array}{l}\text { 1. I can make personal donations to patients on mobile social platforms } \\
\text { whenever I wish to do so myself. } \\
\text { 2. If finances permit, I make personal donations to patients on mobile } \\
\text { social media platforms. } \\
\text { 3. If the donation process was easy to follow, I would make a personal } \\
\text { donation to the patient on the mobile social media platform. }\end{array}$ & Ajzen (1991); \\
\hline Intention to donate & $\begin{array}{l}\text { 1. I have an intention to donate to personal medical crowdfunding projects } \\
\text { appearing on MSNS in the near future. } \\
\text { 2. I plan to donate to personal medical crowdfunding projects appearing on } \\
\text { MSNS in the near future. } \\
\text { 3. I have an intention to donate to personal medical crowdfunding projects } \\
\text { appearing on MSNS if I have a chance to do so. }\end{array}$ & $\begin{array}{l}\text { Partially adapted from } \\
\text { Sura et al. (2017) }\end{array}$ \\
\hline
\end{tabular}


Qihua Liu is a Professor of Information Systems at the School of management, Hainan University. He obtained BS (information management and information systems) and PhD (management science and engineering) from Wuhan University. His research interests involve online user behavior, information systems, electronic commerce and electronic library. His publications have appeared in Electronic Commerce Research, Computers in Human Behavior, Expert Systems with Applications, Int. J. Mobile Communications, Int. J. Ad Hoc and Ubiquitous Computing, Journal of Theoretical and Applied Electronic Commerce Research, Library and Information Science Research, Program-electronic library and information systems, The Electronic Library, Library Hi Tech and in the proceedings of some international conferences.

Li Wang is a postgraduate majoring in Enterprise Management in School of Management of Hainan University. She acquired a bachelor's degree in Management from Shandong University. Her research interest is online user behavior and online donation.

Jingyi Zhou is doing post-doctoral research in Hainan University. She acquired her bachelor's degree in Computer Engineering, Master's degree in Business Administration and Doctor's degree in Business Administration from Silla University. Her main research interests are e-commerce, marketing and information management.

Wei Wu is a lecturer in the Business Administration, School of International Education, Huanghuai University. She received the MSc. degree in international business from Coventry University, UK. She is a PhD candidate of business administration at Hainan University. Her main research interest is consumer behavior and marketing.

Yiran Li is a lecturer of business administration in the School of Management, Zhejiang University of Technology, China. She received a BSc. degree in Computer Science and Technology from Minzu University of China, China, the MSc. degree in Advanced Computer Science and Information Technology Management from The University of Manchester, UK, and PhD degree in electronic commerce from Wuhan University, China. Her main research areas are online user behavior, data mining and business intelligence, cognitive neuroscience, electronic commerce, and information systems. Her publications have appeared in Behaviour and Information Technology, Library and Information Science Research, Electronic Commerce Research and in the proceedings of some international conferences. 